\title{
Family influences on the career journeys of women executive chefs in New Zealand
}

\section{Beverly (Shih-Yun) Chen}

\author{
Beverly (Shih-Yun) is a \\ lecturer at the Auckland \\ Institute of Studies in New \\ Zealand. Her research \\ interests include the chef \\ industry, food and \\ beverage industry trends, \\ gender and careers, and \\ private training education \\ performance.
}

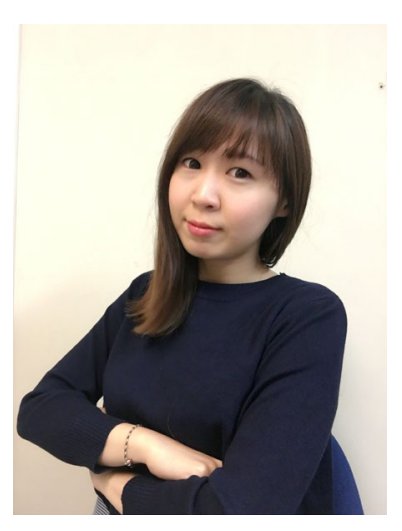

Working in professional kitchens, women chefs face multiple challenges including gender segregation and stereotyping, unfair human-resource policies and procedures, exclusion from professional networks, lack of work-life balance and lack of support [1]. Under these circumstances, it is not surprising that few women chefs progress to prime positions in professional kitchens. Although many leave the industry, some women chefs have persevered and succeeded in attaining executive roles. These women's success stories, and how they have been achieved, are worth examining in order to benefit the growth of the chef sector.

The aim of the research reported in this article [2] was to explore the life histories of women executive chefs in order to understand how it has influenced their careers. Previous studies have described the working environments of chefs but have not captured women's perspectives [3,4]. This study therefore aimed to understand how women chefs progress in the profession, what their experiences have been, and what influences their professional trajectories.

The study adopted a life-history research approach to allow participants' lives and experiences to be made visible [5]. The interview participants were 23 women executive chefs who were, or had been, managing commercial kitchens in New Zealand, with professional responsibilities including financial control, menu design, food production, and leading a team of kitchen staff. The participants had been in the industry between seven and more than 40 years. Most were executive chefs at their own establishments; six were employees of chained establishments or fine-dining restaurants; and three had since moved on to other paths in the industry, such as education or owning a food-related business.

When examining the women's trajectories into an executive chef position, a notable finding was that family was found to have strong influence on their career journeys, including changes in career direction and career length. Out of the 23 participants, 21 (91\%) mentioned the influence of their family of origin on their career choices. It was clear that parents' opinions about the chef profession and families' expectations and needs had been a strong influence on the women's interest in becoming a chef and their resulting professional pathways. Further, participants particularly valued the support from their family throughout their professional careers. Being a chef is demanding, and the participants considered support from family had helped sustain their professional advancement.

Changes in family circumstances, such as getting married or becoming partnered, also influenced the women's career progression. In this research, 
having children was identified as the main obstacle to women chefs' career advancement and the main cause of women leaving the chef profession. Furthermore, many participants expressed concerns about conflict between work and family responsibilities because, on top of the long hours and demands of their work environments, they were also the primary caregivers in their families and performed most of the household tasks. Different strategies were applied by the participants to resolve work-family conflicts. Some sought childcare help from family or professional services; in search of more flexible work schedules, some had left their jobs to work in other establishments in the hospitality industry or opened their own establishments; and some took a break from the kitchen to focus on childcare and domestic responsibilities. This finding explains the predominance in the participant profiles, mentioned above, of women executive chefs either owning their own establishments or having left their executive roles.

By revealing women executive chefs' stories, this research has contributed new insights into the challenges they encounter during their careers. The importance of parental support in the development and growth of women chefs in the professional kitchen is emphasised. At the same time, the study urges food and beverage establishments to provide a family-friendly environment and to develop policies and procedures that allow work-life balance for women within the industry.

The full research project can be accessed here: $\underline{\text { http://hdl.handle.net/10292/14323 }}$

\section{Corresponding author}

Beverly (Shih-Yun) Chen can be contacted at beverlyc@ais.ac.nz

\section{References}

(1) Harris, D. A.; Giuffre, P. Taking the Heat: Women Chefs and Gender Inequality in the Professional Kitchen; Rutgers University Press, 2015.

(2) Chen, S. Y. (B.) Experiences of Women Executive Chefs: A Life History Approach; Doctoral thesis, Auckland University of Technology, New Zealand, 2021. http://hdl.handle.net/10292/14323

(3) Cameron, D. S. Organizational and Occupational Commitment: Exploring Chefs from a Cultural Perspective; Doctoral thesis, University of Surrey, England, 2004. http://epubs.surrey.ac.uk/851494/

(4) Robinson, R. N. S.; Solnet, D. J.; Breakey, N. A. Phenomenological Approach to Hospitality Management Research: Chefs' Occupational Commitment. International Journal of Hospitality Management 2014, 43, 65-75. https://doi.org/10.1016/j.ijhm.2014.08.004

(5) Sosulski, M.; Buchanan, N.; Donnell, C. Life History and Narrative Analysis: Feminist Methodologies Contextualizing Black Women's Experiences with Severe Mental Illness. The Journal of Sociology $\mathcal{E}$ Social Welfare 2010, $37 \quad$ (3), $29-57$. http://scholarworks.wmich.edu/jssw/vol37/iss3/4 